7. Guthrie TC. Visual and motor changes in patients with multiple sclerosis: a result of induced changes in environmental temperature. Arch Neurol Psychiatry 1951;65:437-451.

8. Nelson DA, Jeffreys WH, McDowell F. Effects of induced hyperthermia on some neurological diseases. Arch Neurol Psychiatry 1958;79:31-39

9. Stone LA, Jankovic J. The coexistence of tics and dystonia. Arch Neurol 1991;48:862-865.

10. Watson CW. Effect of lowering of body temperature on the symptoms and signs of multiple sclerosis. N Engl J Med 1959;261:1253-1259.

11. Honan WP, Heron JR, Foster DH, Snelgar RS. Paradoxical effects of temperature in multiple sclerosis. J Neurol Neurosurg Psychiatry 1987;50:1160-1164.

12. Harbord MG, Kobayashi JS. Fever producing ballismus in patients with choreoathetosis. J Child Neurol 1991:6:49-52.

13. Arbisi A, Depue RA, Spoont MR, Leon A, Ainsworth A. Psychiatry Res 1989;28:323-334.

14. Bornstein RA, Stefl ME, Hammond L. A survey of Tourette syndrome patients and their families: the 1987 Ohio Tourette syndrome study. J Neuropsychiatry 1990;2:275-281.

15. Nadel ER, Bullard RW, Stolwijk JAJ. Importance of skin temperature in the regulation of sweating. J Appl Physiol 1971;31:80-87.

16. Gonzales MC, Arevalo R, Castro R, Diaz-Palarea MD, Rodriguez M Different roles of intrahypothalamic and nigrostriatal dopaminergic systems in thermoregulatory response of the rat. Life Sci 1986;39:707-715

17. Lee TF, Mora F, Myers RD. Dopamine and thermoregulation: an evaluation with special reference to dopaminergic pathways. Neurose Biobehav Rev 1985;9:589-598.

18. Gordon CJ, Heath JE. Integration and central processing in temperature regulation. Annu Rev Physiol 1986;48:595-612.

\section{Flunarizine and essential tremor}

To the Editor: We read with interest the article by Biary et al ${ }^{1}$ about the effect of flunarizine (FNZ) on essential tremor (ET). The authors have shown that FNZ is effective in suppressing ET, and no side effects were observed. This finding again raises interest in calcium channel blockers (CCB) on neurologic disorders.

However, we have to point out that FNZ, as well as cinnarizine (CNZ), is a potent antidopaminergic drug and can induce parkinsonism in humans ${ }^{2-7}$ and in primates. ${ }^{8}$ In Europe, FNZ and $\mathrm{CNZ}$ are widely used, and we have been witness to an "epidemic parkinsonism" due to these drugs, mainly affecting older individuals. CCB-induced parkinsonism improves after drug discontinuation, but in many patients some symptoms, especially tremor, do not disappear with the passage of time. Epidemiologic data of some series suggest that patients with ET, and even patients with familial history of ET, are prone to develop iatrogenic parkinsonism. ${ }^{6}$ Therefore, although we accept that FNZ may be useful in relieving temporal ET, we must be cautious because of the risk of iatrogenic parkinsonism as well, especially in older individuals with ET.

Based on the above arguments, we would not recommend the long-term use of FNZ on older patients with ET.

Félix Javier Jiménez-Jiménez, $M D, P h D$ Pedro José García-Ruiz, MD, PhD

Madrid, Spain

\section{References}

1. Biary N, Al Deeb SM, Langenberg $P$. The effect of flunarizine on essential tremor. Neurology 1991;41:311-312.

2. Martí-Massó JF, Carrera N, De la Puente E. Posible parkinsonismo por cinarizina. Med Clin (Bare) 1985;85:614-616.

3. Chouza C, Caamaño JL, Aljanati R, Scarameli A, De Medina D, Romero S. Parkinsonism, tardive dyskinesia, akathisia, and depression induced by flunarizine. Lancet $1986 ; 1: 1303-1304$.

4. Micheli F, Pardal MF, Gatto M, et al. Flunarizine- and cinnarizineinduced extrapyramidal reactions. Neurology 1987;37:881-884.

5. Micheli FE, Fernández Pardal M, Giannaula R, et al. Movement dis. orders and depression due to flunarizine and cinnarizine. Mov Disord 1989;4:139-146.

6. Giménez-Roldán S, Mateo D. Cinnarizine-induced parkinsonism. Susceptibility related to aging and essential tremor. Clin Neuropharmacol 1991:14:156-164.

7. García-Ruiz P, García de Yébenes J, Jiménez-Jiménez FJ, Vázquez A Urra DG, Morales B. Parkinsonism associated to calcium channel blockers (CCB). A prospective follow-up study. Clin Neuropharmacol 1992;15:19-26.

8. García-Ruiz P, Mena MA, Peñafiel N, Garcia de Yébenes J. Cinnarizine induced parkinsonism in primates. Clin Neuropharmacol 1992;15:152-154.

\title{
Correction
}

The correspondence "Immunoglobulins and stroke," published in the September issue of Neurology (1992;42:1847), was signed by Dr. Mark A. Ross only. The signatories should have included James A. Goeken, MD, from Iowa City, IA, and A. Arturo Leis, MD, from Houston, TX, whose names were inadvertently omitted. The editors apologize for the error. 


\title{
Neurology
}

\author{
Correction \\ Neurology 1993;43;239-239-a \\ DOI 10.1212/WNL.43.1_Part_1.239-a
}

This information is current as of January 1,1993

\section{Updated Information \&} Services

Permissions \& Licensing

Reprints including high resolution figures, can be found at: http://n.neurology.org/content/43/1_Part_1/239.2.citation.full

Information about reproducing this article in parts (figures,tables) or in its entirety can be found online at:

http://www.neurology.org/about/about_the_journal\#permissions

Information about ordering reprints can be found online:

http://n.neurology.org/subscribers/advertise

Neurology $\AA$ is the official journal of the American Academy of Neurology. Published continuously since 1951, it is now a weekly with 48 issues per year. Copyright (C) 1993 by the American Academy of Neurology. All rights reserved. Print ISSN: 0028-3878. Online ISSN: 1526-632X.

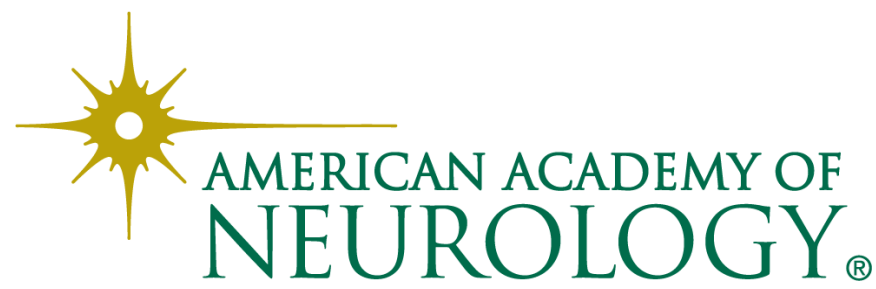

